\title{
ТЕНДЕНЦІЇ РОЗВИТКУ РЕГІОНАЛЬНОЇ МЕРЕЖІ БАНКІВСЬКИХ ВІДДІЛЕНЬ В УКРАЇНІ
}

Розвиток банківського бізнесу, як складної динамічної системи, пов'язаний з розвитком філійної мережі банків. 3 огляду на це, важливого значення набуває розроблення напрямів інноваційного розвитку мережі банківських відділень, спрямованих на забезпечення очікуваних результатів та підвищення ефективності їх діяльності, яку дедалі складніше забезпечити в умовах активного впровадження інноваційних систем дистанційного банківського обслуговування та стрімкого розвитку небанківських фінансових установ. Визначено важливість розвитку регіональної мережі банків, розглянуто тенденції розвитку банківських відділень в Україні. Проаналізовано динаміку зміни відділень банку протягом останніх 9 років. Обгрунтовано причини, через які банки закривають мережі відділень. З'ясовано тенденції в банківській системі України щодо згортання та розширення мережі відділень. Проаналізовано динаміку змін у структурі відділень банків із державною часткою, банків іноземних банківських груп та банків із приватним капіталом. Встановлено, що характерною ознакою для банківської системи України є асиметричність ії територіальної структури, тому досліджено розміщення банківських відділень по регіонах України. Обгрунтовано причини закриття та розширення мережі відділень банків. Запропоновано напрями з удосконалення роботи мережі банківських відділень.

Ключові слова: банківська система; мережа відділень; територіальна структура мережі відділень; інноваційні моделі банківських відділень.

Вступ. Банківська система повинна бути розвинена адекватно реальному сектору економіки і потребам населення та забезпечувати високу стійкість функціонування. Регіональна банківська система повинна бути здатною забезпечувати попит промислових, торговельних підприємств і організацій, малого бізнесу, потреби населення в усьому спектрі форм банківського обслуговування і ресурсах. Особливо ефективно вона повинна виконувати функцію трансформації заощаджень в інвестиції на рівні регіону. Ресурси суб'єктів господарювання регіону повинні бути мобілізовані в регіоні навіть у тому випадку, якщо деякий час вони будуть працювати у фінансовій сфері. Як наслідок - прибуток від таких операцій буде в банків регіону, стимулюючи винятково важливий процес капіталізації банківської системи, який необхідний для стійкого проведення інвестиційних операцій. Звідси і випливає головна роль та специфіка діяльності банківської системи на рівні регіону.

Матеріали та методика дослідження. Вагомий внесок у вирішення проблем функціонування банків на рівні регіонів зробили такі вчені, як: О. Барановський, М. Долішній, В. Коваленко, В. Міщенко та ін. Окремі питання щодо політики регіонального розвитку банківської системи України дослідив О. Другов. Науковці У. Груздевич, В. Зеленюк, М. Могильницька заклали той науковий фундамент, на який можна орієнтуватися у дослідженнях регіонального аспекту розвитку банківської системи України.
Мета роботи - теоретичне дослідження чинників та особливостей розвитку мережі банківських установ у регіонах України.

Результати дослідження. За 26 років незалежності України банківська система пережила мінімум п'ять великих криз (1994р., 1998 р., 2004 р., 2008-2009 рр., 2014-2015 pp.), але остання була найглибшою і найболючішою для економіки. У період "кредитного буму" в Україні, у 2001-2007 pp., екстенсивні стратегії розвитку бізнесу банків супроводжувалися активним нарощуванням філійної мережі, що забезпечувало банкам рентабельну діяльність. При цьому процес створення філійної мережі часто відбувався стихійно, без належного економічного обгрунтування їх доцільності та ефективності. Результатом такої політики став затратний характер діяльності багатьох філій та відділень банків, що призвело до їх закриття. Іншими словами, економічна криза та іï наслідки внесли свої корективи в загальні закономірності та особливості розвитку філійної мережі банків, що проявилося у зменшенні кількості філій і відділень у регіонах (Systema, 2016; Karcheva, 2015; Kopilyuk, 2014).

Тенденція скорочення філійної мережі банків посилюється під впливом впровадження інноваційних систем дистанційного банкінгу, автоматів самообслуговування клієнтів, що не потребує відвідування клієнтами відділень і філій банків, натомість на такій основі зростає інституційна наповненість ринку високотехнологіч-

Інформація про авторів:

Дребот Наталія Петрівна, канд. екон. наук, доцент, кафедра фінансів, банківської справи і страхування.

Email: drebot72@gmail.com

Цитування за Дсту: Дребот Н. П. Тенденції розвитку регіональної мережі банківських відділень в Україні. Науковий вісник НЛту України. Серія Економічна. 2018, т. 28, № 4. С. 52-55

Citation APA: Drebot, N. P. (2018). The Trends in the Development of a Regional Network of Bank Branches in Ukraine. Scientific Bulletin of UNFU, 28(4), 52-55. https://doi.org/10.15421/40280409 
ними банківськими послугами (Karcheva, 2015; Kopilyuk, 2014).

Упродовж 2014-2017 рр. в Україні до категорії неплатоспроможних було віднесено 88 банків, майже всі 3 яких - комерційні. Такі дані оприлюднив Нацбанк. Зокрема, у 2014 р. "луснули" 33 банки, стільки ж - у 2015 р., 21 - у 2016 р., один ("Платинум Банк") - у 2017 р. Із цих 88 банків на повну ліквідацію відправили 81 фінустанову (Banky, 2013). Рішення стосовно 6 банків ще не ухвалили. Тільки один відновив роботу - китайський інвестор купив український державний банк. Фонд державного майна України та Bohai Commodity Exchange Co., Ltd (BОCE) 08.06.2017 р. уклали договір купівлі-продажу 99,9 \% акцій Українського банку реконструкції і розвитку. Також наприкінці 2016 р. відбулася націоналізація найбільшого комерційного банку - "ПриватБанку", який стовідсотково перейшов у державну власність (Kopilyuk, 2014; Sluzhba, 2012; Viddilenia, 2017).

За даними НБУ, на 1 жовтня 2017 р. в Україні було 9 715 відділень банків. Велика частина (5 551 ) з них припадає тільки на два держбанки - Ощадбанк та ПриватБанк. Але якраз ці два "монстри" - одні з найактивніших у закритті відділень. Так, якщо в 2009 р. в Україні налічувалося понад 22000 відділень, то до 1 жовтня 2017 р. їх закрилося більше, ніж половина - 11374. Третина з них - відділення Ощаду та Привату. Одна 3 головних причин, через яку банки згортають мережі банальна потреба економити. Піки закриття відділень та скорочення персоналу припадають на періоди криз 2009 i 2014 pp.

Мережа Ощадбанку - унікальна спадщина від радянського Ощадбанку у вигляді застарілих ощадкас. Сьогодні Ощад реформує свою мережу. Так, банк постійно відкриває відділення нового формату, кількість яких вже досягло 535. При цьому Ощад закриває маленькі відділення з одним робочим місцем, адже, по суті, це ощадкаса, яка не може задовольнити потреби клієнтів. Також Ощад активно розвиває дистанційні канали. Зараз кількість користувачів інтернет-банку Ощад 24/7 перевищило 2,1 млн осіб. Якщо в 2014 р. частка операцій, проведених у дистанційних каналах, становила $22 \%$, то за підсумками 2017 р. - 50 \% від загальної кількості.

Одна 3 головних причин закриття відділень ПриватБанку - це анексія Криму та АТО на сході країни. 3 огляду на ці факти, Привату довелося закрити 955 відділень, 3 них 236 - тимчасово. Темпи скорочення банківських відділень у 2017 р. дещо сповільнилися: якщо за 2017 р. було закрито 8 \% наявних відділень (827 підрозділів), то за 2016 р. - 13,1 \% підрозділів (1555 філій) (рисунок).

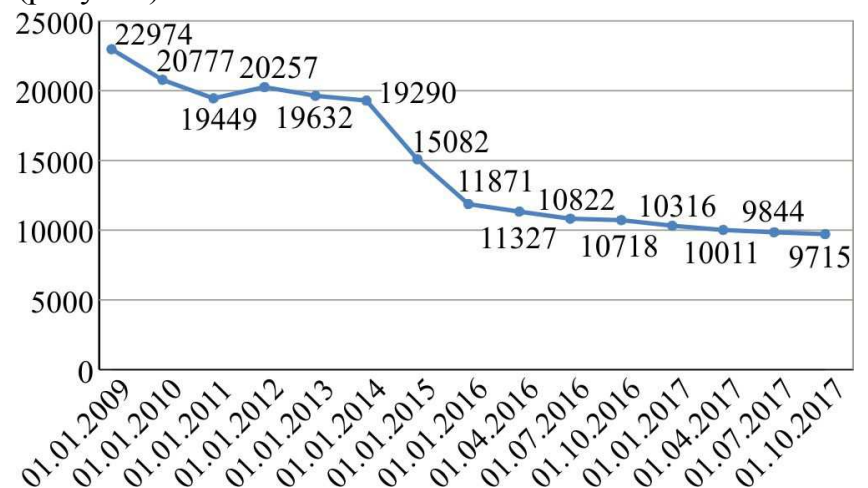

Рисунок. Скорочення відділень за 9 років. Авторська розробка на основі (Sluzhba, 2012; Viddilenia, 2017)
Упродовж 2017 р. банки продовжують згортати мережі. Порівняно зі жовтнем 2016 р., на 1 жовтня 2017 р. кількість робочих відділень скоротилася на більш ніж 1 000. Активніше за інших, за традицією, свої відділення закривали Ощадбанк та ПриватБанк - на них сумарно припадає 576 закритих точок.

3 великим ентузіазмом відділення також закривали "іноземці". Так, 3 банки із західним капіталом - УкрСибБанк, Райффайзен, Банк Аваль та Правекс-Банк закрили за рік 165 відділень, і два банки з російським Сбербанк й ВТБ - ще 51 (Sluzhba, 2012; Viddilenia, 2017. Усі вони продовжують тренд часів глобальної кризи 2009 р., а саме - скорочення витрат через згортання територіальної мережі. Така економія вже принесла свої плоди - жодного європейського банку не було ліквідовано під час двох останніх "банкопадів". Іноземні банки показують максимальну ефективність операційних витрат і слідують глобальним тенденціям у діджіталізації банківських послуг. Вони розуміють, що в новій цифровій економіці банкам не потрібно стільки відділень, як раніше, якщо $є$ змога створити зручний інтернет-банкінг.

Як відомо, для банківської системи України характерна асиметричність територіальної структури банківської системи України та значні диспропорції розвитку її регіональних систем, що негативно впливає не тільки на доступність банківських послуг населенню, але й призводить до дисбалансів у соціально-економічному розвитку регіонів, які залежать від демографічної ситуації, паливно-сировинних ресурсів, розвитку інфраструктури, економіки регіонів тощо. Тому географія закриття банківських відділень не була рівномірною. Кількість філій фінустанов найбільше скоротилася в Києві - на 63 відділення і в Дніпропетровській обл. - на 57 відділень. А загалом банки згортали свої мережі частіше в Центральній частині України. У регіоні закрилося 176 відділень банків або майже 7 \% від їх загальної кількості (Kopilyuk, 2014; Sluzhba, 2012; Viddilenia, 2017).

У Центрі найбільш помітно скорочувався Ощадбанк (108 закритих відділень за 9 місяців), а УкрСибБанк і Правекс-Банк, які розділили друге і третє місце, ліквідували по 6 філій. Аналогічна "трійка" і в Північному регіоні - Ощадбанк закрив 86 відділень, Правекс-Банк 14, а УкрСибБанк - 5. На Заході знову найактивніше скорочував мережу Ощадбанк - мінус 103 філії. На другому місці - УкрСибБанк (8 закритих відділень), а на третьому - Банк Січ (7 відділень). На Півдні також виділився Ощадбанк з 24 закритими філіями, УкрСибБанк - мінус 13 відділень і Укрсоцбанк - мінус 6. Не став винятком і Схід. Тут присутність Ощадбанку скоротилося на 26 відділень. На другому місці опинився Скай Банк, який закрив 6 відділень у Харкові (ще одне було перейменоване і змінило адресу). Третє розділили Правекс-Банк і Мегабанк - по 4 закритих відділення. Найбільше відрізнялася ситуація у столиці. На відміну від інших регіонів, тут найбільш помітно скорочувався Айбокс Банк. Установа за 9 місяців закрила 17 відділень у Києві. Роботу 13 філій припинив Правекс-Банк і 7 філій - Прокредит Банк.

Аналізуючи розміщення банківських відділень по регіонах України, у п'ятірку лідерів входять м. Київ (1195 відділень із загальної кількості 9 715), Дніпропетровська обл. (886 відділень), Одеська та Харківська обл. 
(729 та 728 відділень відповідно), Львівська обл. (645 відділень). Найменше відділень виявилося в Луганській та Тернопільській обл. Тут їх налічується 136 й 166 відповідно.

Але знайшлися й фінустанови, які за рік розширили свою мережу відділень, таких в Україні виявилося 24. Найбільше мережу наростив Альфа-Банк. Серед інших великих гравців, які збільшили кількість відділень Укргазбанк, ТАСкомбанк, Банк Інвестицій та Заощаджень, а також ПУМБ.

За січень - жовтень 2017 р. активніше за інших відділення розширював Альфа-Банк. Він відкрив 85 нових відділень. Друге місце посів Кредит Оптима Банк - 34 відкритих філій, і на третьому - Укрбудінвестбанк плюс 19 відділень (Sluzhba, 2012; Viddilenia, 2017.

Якщо розглядати ситуацію не за кількістю відкритих відділень, а за динамікою, то найбільший приріст продемонстрував Кредит Оптима Банк із показником у 1650 \%. Однак у листопаді 2017 р. акціонери цієї фінустанови ухвалили рішення про припинення його діяльності. Окрім нього, помітно (на 300 \%) зросли Банк Альянс і на $100 \%$ - Укрбудінвестбанк.

Переважно мережу розширювали приватні вітчизняні банки середнього ешелону. Вони в такий спосіб намагалися перейти від старої корпоративної, зокрема, "кишенькової" і схемної, бізнес-моделі до розвитку більш життєздатного універсального банкінгу. Це стало можливим завдяки розширенню роздрібних банківських послуг, для яких важливим є широке регіональне охоплення. Ці банки взяли курс на проникнення у перспективні регіони, де раніше не вели бізнес.

3 розвитком технологій, банки отримали дешевші канали взаємодії з клієнтами, бо з-поміж усіх каналів відділення - це найдорожче. Сьогодні в кол-центрах і онлайн-чатах фінпослуги надають роботи, а у відділеннях банків щоразу більше зон самообслуговування. Банки намагаються перевести клієнтів на дистанційні канали обслуговування, зводячи до мінімуму індивідуальне спілкування.

Цікаво, що 2016-2017 рр. були періодом інтенсивного розвитку ринку мобільних додатків. Загалом у 2016 р. був бум на нові продукти і послуги. Один із таких - новий вид платежів, що з'єднує рахунки з доступом через інтернет-банкінг або електронні гаманці й онлайн-магазини. Фінустанови поступово переводять операції в мережу. Здійснити платіж або оформити депозит можна як за допомогою комп'ютера, так і смартфона. Через це відділення стають непотрібним вантажем, який просто з'їдає прибуток.

Отже, по всьому світу банки цілеспрямовано згортають мережі. Наприклад, у Німеччині у 2014-2015 pp. було закрито 2200 відділень кредитно-фінансових установ. Загалом із 2000 р., коли у ФРН працювали 38 тис. банківських філій, закрито кожне четверте відділення. Їх кількість зменшилась на 10,2 тис. Банки продовжують закривати свої офіси і цього року. Якщо тенденція збережеться, то до 2035 р. в Німеччині залишиться тільки половина філій, які були на початку тисячоліття (Banky, 2015).

У 2018 р. націоналізований ПриватБанк планує скоротити мережу відділень від 2213 до 2061, щоб оптимізувати малоефективні міні-відділення банку з невели- кою кількістю персоналу. У програмі розвитку мережі обслуговування банку заплановано відкриття впродовж року 49 нових універсальних відділень. Окрім цього, 73 відділення ПриватБанку "переїдуть" у зручніше для клієнтів місце розташування та зможуть надавати повний комплекс банківських послуг фізичним і юридичним особам. Оновлена мережа відділень ПриватБанку до кінця 2018 р. буде налічувати 2061 філію та відділення. Також банк планує впродовж року збільшити мережу банкоматів на $3 \%$ - до 7 795, а мережа торгових POS-терміналів зросте на $13 \%$ - до 170 тис. (Banky, 2013).

Висновки. Отже, причинами закриття банківських відділень є: "банкопад" у 2014-2017 рр.; орієнтація банків на економію від відсоткових витрат за депозитами до звільнення персоналу і скорочення операційних витрат; скорочення старих точок для того, щоб відкривати нові сучасні пункти або розвивати інтернет-банкінг. Як результат, державні банки стали лідерами за кількістю закритих відділень.

У 2018 р. очікується закриття ще частини банків i скорочення банківських мереж. Більшість великих гравців із державними та іноземними власниками і далі будуть заміщати неефективні підрозділи інтернет-банкінгом. 3 погляду довготермінових стратегій, лідери ринку будуть змушені слідувати глобальному тренду, активно розвиваючи співпрацю 3 fintech-компаніями, акцентуючи увагу на інноваційний розвиток відділень банків. Інноваційні моделі відділень банків майбутнього називають по-різному: "магазинами", "сервісно-торговими центрами", "кафе", виїзні відділення, автоматизовані відділення та центри обслуговування тощо. Спільним для них $є$ те, що відділення мають істотно змінитися. Із місця здійснення трансакцій перетвориться у місце активної взаємодії із клієнтами і продажу банківських продуктів і послуг, забезпечувати швидке придбання стандартних продуктів, застосування мультимедійних засобів донесення інформації до клієнтів, автоматизацію, самообслуговуванню тощо.

\section{Перелік використаних джерел}

Banky. (2013). Ofitsiinyi sait Natsionalnoho banku Ukrainy [Official website of the National Bank of Ukraine]. Retrieved from: http://www.bank.gov.ua/. [In Ukrainian].

Banky. (2015). Maibutnie bankivskoi systemy Ukrainy [Future of the banking system of Ukraine]. Retrieved from: http://www.bank.gov.ua/control/uk/publish/artic-

le?art_id=12504076. [In Ukrainian].

Karcheva, I. Ya. (2015). Modern tendencies of innovation development of Ukrainian banks in the context of Bank concept 3.0. Financial space, 3(19), 299-309. Retrieved from: http://fp.cibs.ck.ua

Kopilyuk, O. I. (2014). Regional Policy of the Banking System Development Ukraine. Odessa: Institute of Market Problems and Economic and Environmental Studies of the National Academy of Sciences of Ukraine. $576 \mathrm{p}$.

Sluzhba. (2012). Ofitsiinyi sait Derzhavnoi sluzhby statystyky Ukrainy [Official website of the State Statistics Service of Ukraine]. Retrieved from: www. ukrstat.gov.ua. [In Ukrainian].

Systema. (2016). Didzhytalizatsiia bankivskoi systemy [Dizigitalization of the banking system]. Retrieved from: http://www.slideshare.net/tribotinka/ss-63384661. [In Ukrainian].

Viddilenia. (2017). Yak banky pozbavlialysia vid viddilen u 2017 rotsi [How banks got rid of offices in 2017]. Retrieved from: https://minfin.com.ua/ua/2018/01/17/31946582/. [In Ukrainian]. 


\section{ТЕНДЕНЦИИ РАЗВИТИЯ РЕГИОНАЛЬНОЙ СЕТИ БАНКОВСКИХ ОТДЕЛЕНИЙ В УКРАИНЕ}

Развитие банковского бизнеса, как сложной динамической системы, связано с развитием филиальной сети банков. В связи с этим важное значение приобретает разработка направлений инновационного развития сети банковских отделений, направленных на обеспечение ожидаемых результатов и повышение эффективности их деятельности, которую все сложнее обеспечить в условиях активного внедрения инновационных систем дистанционного банковского обслуживания и стремительного развития небанковских финансовых учреждений. Учитывая изложенное выше, определена важность развития региональной сети банков, рассмотрены тенденции развития банковских отделений в Украине. Проанализирована динамика изменения отделений банка в течение последних 9 лет. Обоснованы причины, по которым банки закрывают сеть отделений. Выяснены тенденции в банковской системе Украины по сворачиванию и расширению сети отделений. Проанализирована динамика изменений в структуре отделений банков с государственным долевым участием, банков иностранных банковских групп и банков с частным капиталом. Установлено, что характерным признаком для банковской системы Украины является асимметричность ее территориальной структуры, поэтому исследована концентрация банковских отделений по регионам Украины. Обоснованы причины закрытия и расширения сети отделений банков. Предложены направления по совершенствованию работы сети банковских отделений.

Ключевые слова: банковская система; сеть отделений, территориальная структура сети отделений; инновационные модели банковских отделений.

N. P. Drebot

Lviv Educational and Research Institute of Banking University, Lviv, Ukraine

\section{THE TRENDS IN THE DEVELOPMENT OF A REGIONAL NETWORK OF BANK BRANCHES IN UKRAINE}

The development of banking business as a complex dynamic system is associated with the development of a network of banks. The latest trends in the development of the banking sector in the world illustrate the gradual shift from the product-oriented approach of banking organization to the client-oriented one. The emphasis was put on the maximal satisfaction of client's needs as well as on the expanding the range of services provided. The rapid development of IT technologies and the usage of mobile applications partly improved some services of the banking sector. Banks are changing the business model of work with the client base, striving to minimize contact with their clients, providing a wide range of banking and consulting services remotely. Moreover, they optimize sales networks and costs associated with it. Bank department is the most expensive way of attracting and servicing clients, which makes banking institutions close chains of departments. Therefore, the purpose of the study is to substantiate the peculiarities of the development of banking institutions in various regions of Ukraine. The study has determined the importance of development of the regional network of banks. It has considered the trends of development of bank branches in Ukraine. In addition, the research has analyzed the dynamic of changes in bank branches during the last 9 years. For example, it has provided the reasons why banks close their departments. Moreover, the study has revealed the tendencies in the banking system of Ukraine concerning the curtailment and expansion of the department branches. The authors have analyzed the dynamics of changes in the structure of banks with a state share, banks of foreign banking groups and banks with a private capital. Additionally, the research has elucidated the characteristic feature of the banking system of Ukraine: the asymmetry of its territorial structure. Consequently, we have analyzed the concentration of bank branches in the regions of Ukraine as well. We have substantiated the reasons of closing and expanding the chains of banks. Finally, the authors have offered the ways of improving the work of bank branches.

Keywords: banking system; network of branches; territorial structure of the network of branches; innovative models of bank branches.

Дребот Наталія Петрівна, канд. екон. наук, доцент, кафедра фінансів, банківської справи і страхування. Email: drebot72@gmail.com 